\title{
Analisis Sebaran Daerah Rawan Longsor Menggunakan Remote Sensing dan Analytical Hierarchy Process (AHP) di Kabupaten Magelang Provinsi Jawa Tengah
}

\author{
Aisyah Nur Isneni ${ }^{1}$, Thomas Triadi Putranto ${ }^{1}$, Devina Trisnawati ${ }^{1}$ \\ ${ }^{1}$ Departemen Teknik Geologi, Fakultas Teknik, Universitas Diponegoro
}

\begin{abstract}
Abstrak
Kabupaten Magelang merupakan salah satu wilayah di Indonesia yang memiliki intensitas longsor tinggi. Selama tahun 2017-2019 terjadi tanah longsor sebanyak lebih dari 500 kejadian di Kabupaten Magelang. Berdasarkan hal tersebut, penelitian ini berupaya untuk memberikan gambaran persebaran daerah rawan longsor pada Kabupaten Magelang. Penelitian ini menggunakan 4 parameter penyebab terjadinya tanah longsor yaitu parameter kelerengan, parameter litologi, parameter curah hujan, dan parameter tutupan lahan. Parameter tersebut didapatkan dari beberapa metode yang meliputi: pengolahan data citra penginderaan jauh, pengolahan data sistem informasi geografis, dan validasi lapangan. Hasil dari tiap parameter kemudian diberikan bobot dengan menggunakan metode Analytical Hierarchy Process (AHP) untuk mendapatkan hasil akhir berupa peta rawan longsor. Berdasarkan hasil pengolahan yang dilakukan, diketahui sebanyak 10 kecamatan pada Kabupaten Magelang memiliki kelas rawan longsor tinggi, 5 kecamatan termasuk pada kelas sedang, dan 6 kecamatan lainnya termasuk dalam kelas rendah. Tahap validasi dilakukan dengan membandingkan hasil analisis peta dengan data kejadian tanah longsor Kabupaten Magelang 3 tahun terakhir menggunakan matriks konfusi. Hasil dari validasi peta sebaran daerah rawan longsor memiliki akurasi $80,95 \%$, yang artinya tingkat akurasi antara data hasil analisis peta dengan data validasi lapangan baik.
\end{abstract}

Kata kunci: Analytical Hierarchy Process (AHP); Kabupaten Magelang; penginderaan jauh; tanah longsor.

\begin{abstract}
Magelang Regency is one of the regions in Indonesia that has a high landslide intensity. During 20172019 there were more than 500 landslides in Magelang Regency. Based on this matter, this study aims to analyze the distribution of landslide hazard areas in Magelang Regency. This study uses 4 parameters including slope parameter, lithology parameter, rainfall parameter, and land cover parameter. These parameters are resulted from several methods including: processing remote sensing image data, processing geographic information system data, and field validation. The results of each parameter are weighted using the Analytical Hierarchy Process (AHP) method to get the final result of a landslide hazard map. Based on the results of the data processing, it can be seen that: 10 sub-districts in Magelang Regency have high landslide hazard classes, 5 sub-districts are included in the middle class, and 6 other sub-districts are included in the low class. Validation is generated by comparing the results of map analysis with data on the occurrence of landslides in Magelang Regency in few 3 years later using a confusion matrix. The results of the validation, the map of the distribution of landslide hazard areas has an accuracy of $80.95 \%$, which means that the level of accuracy between the data from the map analysis and the field validation data is accurate.
\end{abstract}

Keywords: Analytical Hierarchy Process (AHP); Magelang Regency; remote sensing; landslides.

\footnotetext{
*Korespondensi: isneniaisyah@gmail.com
} 


\section{PENDAHULUAN}

Dalam beberapa tahun terakhir, intensitas terjadinya tanah longsor di Indonesia semakin meningkat dengan sebaran wilayah bencana semakin luas. Salah satunya adalah wilayah Kabupaten Magelang. Tercatat oleh BPBD Kabupaten Magelang dalam 3 tahun terakhir (2017-2019) terjadi tanah longsor dengan skala yang bervariasi sebanyak lebih dari 500 titik di Kabupaten Magelang. Kerusakan dan kerugian yang dihasilkan karena tanah longsor ini bervariasi tergantung dari skala kejadiannya.

Berdasarkan uraian di atas, diperlukan kajian untuk memetakan daerah rawan longsor di Kabupaten Magelang dengan metode yang dapat mencakup luasan daerah secara akurat dan maksimal. Peta sebaran daerah rawan longsor dapat digunakan untuk memprediksi kemungkinan longsor di waktu yang akan datang, selain itu peta tersebut juga berfungsi untuk mitigasi awal dan dapat mengurangi kerugian serta kerusakan yang mungkin dapat ditimbulkan dari tanah longsor. Proses pembuatan peta ini melibatkan beberapa pendekatan kualitatif dan kuantitatif. Berdasarkan Permen PU No.22/PRT/M/2007 beberapa faktor pemicu tanah longsor pada umumnya berupa kondisi kemiringan lereng, jenis batuan, tutupan lahan dan curah hujan.

Informasi tentang faktor-faktor pemicu tanah longsor pada skala regional seperti tutupan lahan dan kemiringan lereng, umumnya diperoleh dari citra penginderaan jauh (Gorum dkk., 2011; Owen dkk, 2008). Penggunaan remote sensing (penginderaan jauh) ini memiliki keunggulan berupa perolehan data yang cepat dan efektif. Banyak penelitian yang telah dilakukan tentang pemetaan daerah rawan longsor dengan memanfaatkan penginderaan jauh. Pada beberapa penelitian sebelumnya, faktor tutupan lahan umumnya didapatkan dari citra resolusi menengah seperti Landsat, MODIS, ASTER dan SPOT-5 (Gorum dkk., 2014; Pradhan, 2010; Owen dkk, 2008; Lodhi, 2011; Temesgen dkk., 2001). Dalam penelitian ini identifikasi tutupan lahan diperoleh dari pengolahan citra resolusi tinggi yaitu citra SPOT-6. Citra SPOT-6 banyak digunakan untuk menganalisis tutupan lahan, misalnya Febrianti, dkk (2015) melakukan analisis ruang terbuka hijau di DKI Jakarta menggunakan data SPOT 6. Penggunaan citra resolusi menengah (Landsat) dirasa masih kurang akurat karena memiliki resolusi spasial yang cukup kecil $(30 \mathrm{~m})$ untuk daerah dengan cakupan wilayah yang luas. Sehingga penggunaan SPOT6 dapat memberikan hasil yang lebih akurat secara luas, mengingat citra SPOT-6 memiliki resolusi spasial 1,5m (pankromatik) - $6 \mathrm{~m}$ (multispektral) (Febrianti dkk., 2015).

Sesuai dengan anjuran Peraturan Kepala BNPB Nomor 02 tahun 2012 tentang Pedoman Umum Pengkajian Risiko Bencana, penentuan nilai bobot tiap parameter menggunakan metode AHP. Penggunaan metode AHP untuk menentukan nilai bobot parameter pemicu terjadinya tanah longsor telah banyak digunakan di berbagai wilayah, misalnya Yalcin (2008) di Ardesen, Turki; Zhang dkk (2016) di Huizhou, China; Bera dkk (2019) di Ghat Barat, India; Kayastha dkk (2019) di Tinau, Nepal Barat. Penggunaan metode AHP ini juga dianggap menghasilkan penilaian dengan akurasi yang cukup tinggi.

Tujuan akhir dari penelitian ini adalah untuk menghasilkan peta persebaran rawan longsor daerah penelitian, yang diharapkan dapat menjadi acuan untuk Pemerintah Daerah dalam mitigasi awal serta perencanaan pembangunan. Secara geografis daerah penelitian berada pada $110^{\circ} 01^{\prime} 51^{\prime \prime}$ sampai $110^{\circ} 26^{\prime} 58^{\prime \prime}$ BT dan $7^{\circ} 19^{\prime} 13^{\prime \prime}$ sampai 7042'16" LS (Gambar 1). Lokasi penelitian merupakan keseluruhan Kabupaten Magelang dengan luas sekitar 108.573 ha.

\section{Citra SPOT-6, CHIRPS, dan DEMNAS}

Satelit Sensor SPOT-6 pertama kali diluncurkan oleh Pusat Antariksa Satish Dawan, India pada tahun 2012 menggunakan roket luar angkasa PSLV. Dataset citra SPOT-6 dapat digunakan untuk pemetaan wilayah, perencanaan daerah perkotaan dan pedesaan, eksplorasi minyak bumi dan gas, serta untuk mengetahui kondisi daerah bencana alam (BDPJN Lapan, 2018). Citra SPOT-6 memiliki resolusi spasial $6 \mathrm{~m}$ untuk citra multipektral dan 1,5 m untuk pankromatik. 


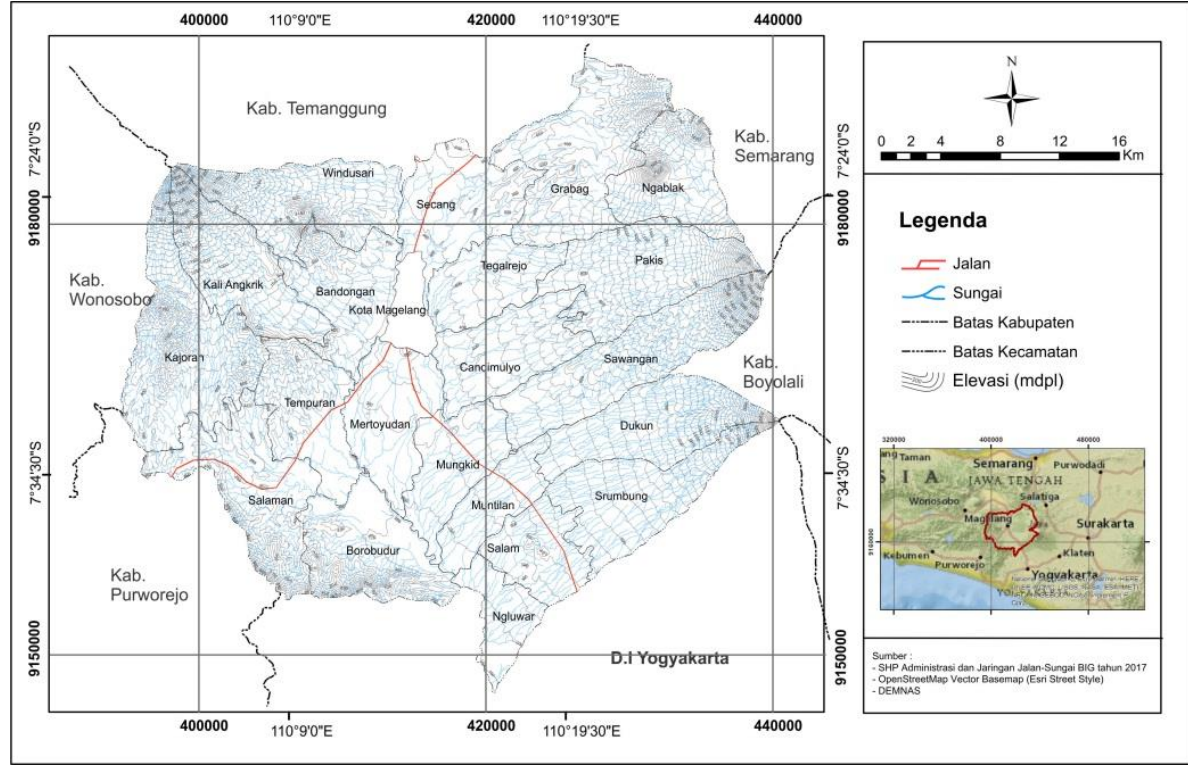

Gambar 1. Lokasi Penelitian

CHIRPS (Climate Hazard group Infrared Precipitation with Station) dikembangkan untuk mendukung Badan FEWS NET, U.S. CHIRPS menggunakan Tropical Rainfall Measuring Mission Multi-satellite Precipitation Analysis versi 7 (TMPA 3B42 v7) untuk mengkalibrasi perkiraan curah hujan berbasis Cold Cloud Duration (CCD) (Funk dkk., 2015). CHIRPS memiliki resolusi tinggi yaitu $0,05^{\circ} \times 0,05^{\circ}$ atau sekitar $5 \mathrm{~km}$.

Digital Elevation Model (DEM) merupakan representatif relief dari permukaan serta informasi ketinggian dari permukaan bumi tanpa ada fitur alam maupun buatan manusia (ASPRS, 2007). Dalam rangka memenuhi kebutuhan DEM di Indonesia, Badan Informasi Geospasial telah meluncurkan DEM Nasional (DEMNAS). DEMNAS dibentuk dari berbadai jenis sumber data, yaitu IFSAR (resolusi 5m), TERRASAR-X (resolusi 5m) dan ALOS PALSAR (resolusi $11,25 \mathrm{~m}$ ), dengan menambahkan data Masspoint hasil stereo-plotting. Resolusi spasial DEMNAS adalah 0,27-arcsecond, dengan menggunakan datum vertikal EGM 2008 (Badan Informasi Geospasial, 2008)

\section{Analytical Hierarchy Process (AHP)}

Pada dasarnya sistem AHP dirancang untuk menghimpun secara rasional persepsi orang yang berhubungan sangat erat dengan permasalahan tertentu melalui suatu prosedur untuk sampai pada suatu skala preferensi di antara berbagai alternatif (Saaty, 1980). Dalam penyelesaian menggunakan sistem AHP terdapat 4 prinsip dasar yang harus dipahami yaitu: Dekomposisi masalah, comparative judgement (perbandingan berpasangan), synthesis of priority (menentukan prioritas), dan logical consistency (perhitungan konsistensi).

Dalam AHP, penetapan prioritas kebijakan dilakukan dengan menangkap secara rasional persepsi orang, kemudian mengkonversi faktorfaktor yang intangible (yang tidak terukur) ke dalam aturan yang biasa, sehingga dapat dibandingkan. Dalam proses penilaian pembobotan akhir yang dilakukan terdapat aturan nilai CR (Consistency Ratio) harus memiliki nilai kurang dari 10\% atau 0,1 (Saaty, 1994).

\section{Matriks Konfusi}

Matriks Konfusi (Confusion matrix) adalah suatu metode yang digunakan untuk melakukan perhitungan akurasi pada konsep data mining, contoh dapat dilihat pada Tabel 1 (Kohavi dan Provost, 1998 dalam Bayuaji, 2016). Pada dasarnya matriks konfusi mengandung informasi yang membandingkan hasil klasifikasi yang dilakukan oleh sistem dengan hasil klasifikasi yang seharusnya (Solichin, 2017).

Tabel 1. Matriks Konfusi (Bayuaji, 2016). 


\begin{tabular}{cccc}
\hline & \multicolumn{2}{c}{ Actual } \\
& & Negative & Positive \\
\hline Predicted & Negative & $\mathrm{a}$ & $\mathrm{c}$ \\
& Positive & $\mathrm{b}$ & $\mathrm{d}$ \\
\hline
\end{tabular}

Keterangan:

a : jika hasil prediksi negatif dan data sebenarnya negatif.

b : jika hasil prediksi positif sedangkan nilai sebenarnya negatif.

c : jika hasil prediksi negatif sedangkan nilai sebenarnya positif.

$\mathrm{d}$ : jika hasil prediksi positif dan nilai sebenarnya positif.

Perhitungan akurasi data dilakukan dengan menggunakan rumus sebagai berikut :

Accuracy $=(\mathrm{a}+\mathrm{d}) /(\mathrm{a}+\mathrm{b}+\mathrm{c}+\mathrm{d})$

\section{METODOLOGI}

Beberapa metode dalam penelitian ini, yaitu pengolahan data penginderaan jauh dan data spasial SIG, pengolahan data AHP, serta validasi peta hasil analisis.

Pengolahan Data Penginderaan Jauh dan Data Spasial SIG

Dataset citra SPOT-6 yang bersumber dari LAPAN digunakan untuk mengidentifikasi parameter tutupan lahan menggunakan platform GEE (Google Earth Engine). Pengolahan parameter tutupan lahan ini menggunakan metode klasifikasi terarah random forest. Klasifikasi diuraikan pada Tabel 2.

Pengolahan DEMNAS untuk menghasilkan parameter kemiringan lereng daerah penelitian dengan pembagian kelas seperti pada Tabel 3 . Data DEMNAS diperoleh dari Badan Informasi Geospasial tahun 2008.

Pengolahan CHIRPS tahun 2015-2019 untuk menghasilkan parameter rata-rata curah hujan. Data CHIRPS didapatkan dari Climate Hazard Center (CHC) UC Santa Barbara. Klasifikasi diuraikan pada Tabel 4.

Pengolahan data spasial berupa peta geologi interpretasi inderaan jauh yang bersumber dari Pusat Survey Geologi oleh Surono (2013) serta validasi lapangan untuk menghasilkan peta sebaran litologi daerah penelitian. Pembagian kelas untuk litologi ditampilkan di Tabel 5.
Tabel 2. Klasifikasi Tutupan Lahan (Pusat Penelitian dan Pengembangan Tanah dan Agroklimat, 2004).

\begin{tabular}{ll}
\hline Parameter & Kelas \\
\hline Perairan & 1 \\
Hutan & 2 \\
Kota / Pemukiman & 3 \\
Lahan terbuka & 4 \\
Sawah/ Perkebunan & 5 \\
\hline
\end{tabular}

Tabel 3. Klasifikasi Kemiringan Lereng (Direktorat Jendral Reboisasi dan Rehabilitasi Lahan, 1986).

\begin{tabular}{lc}
\hline Parameter & Kelas \\
\hline $0 \%-8 \%$ datar & 1 \\
$8 \%-15 \%$ landai & 2 \\
$15 \%$ - 25\% agak curam & 3 \\
$25 \%-45 \%$ curam & 4 \\
$>45 \%$ sangat curam & 5 \\
\hline
\end{tabular}

Tabel 4. Klasifikasi Curah Hujan Tahunan (metode distribusi frekuensi).

\begin{tabular}{lc}
\hline Parameter & Kelas \\
\hline $2.041-2.313 \mathrm{~mm} /$ tahun & 1 \\
$2.313-2.585 \mathrm{~mm} /$ tahun & 2 \\
$2.585-2.856 \mathrm{~mm} /$ tahun & 3 \\
$2.856-3.128 \mathrm{~mm} /$ tahun & 4 \\
$3.128-3.400 \mathrm{~mm} /$ tahun & 5 \\
\hline
\end{tabular}

Tabel 5. Klasifikasi Persebaran Litologi (Pusat Penelitian dan Pengembangan Tanah dan Agroklimat, 2004).

\begin{tabular}{lr}
\hline Parameter & Kelas \\
\hline Alluvium & 1 \\
Batuan Vulkanik & 2 \\
Batuan Sedimen & 3 \\
\hline
\end{tabular}

\section{Pengolahan Data AHP}

Perumusan nilai bobot parameter menggunakan AHP (Gambar 2) mengacu pada data kuisioner perbandingan berpasangan yang diberikan kepada beberapa responden yang terdiri dari akademisi yang merupakan dosen Teknik Geologi dan Teknik Geodesi Universitas Diponegoro (2) dan pemangku kebijakan/stakeholder yang merupakan perangkat kecamatan di Kabupaten Magelang, relawan, dan staff BPBD Kabupaten Magelang (12). Pengolahan data hasil pengambilan nilai dari responden dilakukan pada software Expert Choice 11.

Pembagian kuisioner perbandingan AHP kepada 14 responden dengan masing-masing memiliki persepsi secara kualitatif menghasilkan nilai setiap parameter dan nilai akhir inkonsistensi. 


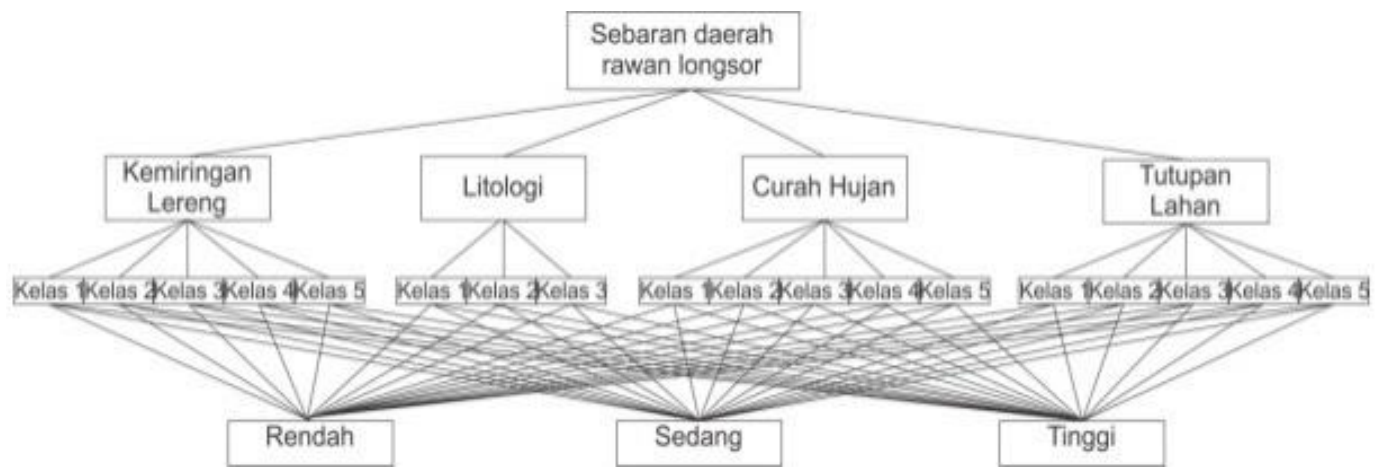

Gambar 2. Model hirarki parameter penyebab tanah longsor dan tingkat kerawanannya.

Batasan nilai yang mengacu pada aturan pengolahan AHP oleh Saaty (1994) yaitu mendapatkan nilai CR atau rasio konsistensi yang lebih rendah dari 0,1 atau $10 \%$. Apabila nilai CR lebih besar dari 0,1 artinya data yang dihasilkan tidak konsisten. Penilaian bobot tiap parameter menggunakan metode AHP kemudian akan menjadi acuan dalam proses overlay peta sebaran daerah rawan longsor Kabupaten Magelang.

\section{Validasi Peta Hasil Analisis}

Hasil peta rawan longsor Kabupaten Magelang divalidasi dengan menggunakan data lapangan yang diperoleh dari BPBD Kabupaten Magelang tahun 2017 - 2019. Data lapangan ini berupa riwayat kejadian bencana tanah longsor di tiap kecamatan. Uji akurasi dilakukan dengan menggunakan matriks konfusi. Dari uji akurasi ini dapat diketahui apakah analisis peta rawan longsor Kabupaten Magelang menggunakan metode AHP sudah sesuai dengan kondisi sebenarnya di lapangan.

\section{HASIL}

\section{Tutupan Lahan}

Hasil klasifikasi tutupan lahan pada Kabupaten Magelang (Gambar 3) menunjukkan dominasi oleh hutan yang tersebar hampir diseluruh wilayah Kabupaten Magelang. Selain itu sawah/perkebunan juga banyak ditemukan diseluruh wilayah Kabupaten Magelang dan biasanya berasosiasi dengan hutan. Lahan terbangun terpusat pada daerah dengan topografi datar dan landai dan umumnya semakin banyak pada wilayah yang mendekati perkotaan. Lahan terbuka tidak banyak ditemukan dalam interpretasi tutupan lahan ini, persebarannya yang sedikit berada pada Kecamatan Dukuh, Srumbung, dan Borobudur. Tubuh air pada Kabupaten Magelang secara umum berupa sungai, terdapat tiga aliran sungai besar pada Kabupaten Magelang yaitu Kali Elo, DAS Progo, dan DAS Bogowonto.

\section{Kemiringan Lereng}

Hasil klasifikasi kemiringan pada Kabupaten Magelang (Gambar 4) menunjukkan dominasi kemiringan lereng datar dengan tingkat persentase kemiringan 0\%-8\% persebarannya berada pada Kecamatan Mertoyudan, Mungkid, Muntilan, Srumbung, dan Ngluwar, dengan luas totalnya sebesar 33.883 ha.

Sementara itu, daerah yang memiliki persen kelerengan sebesar 8\%-15\% dengan tingkatan landai meliputi Kecamatan Mertoyudan, Candimulyo, Tegalrejo, Dukun, Borobudur, dan Secang dengan persebaran totalnya seluas 31.158 ha. Daerah yang yang memiliki persen kelerangan sebesar 15\%-25\% dengan tingkatan agak curam meliputi Kecamatan Grabag, Sawangan, Dukun, Tempuran, Salaman, dan Borobudur yang umumnya mendekati daerah lereng dan kaki gunung, dengan persebaran totalnya seluas 22.632 ha. Daerah yang memiliki persen kelerangan sebesar 25\%-45\% dengan tingkatan curam meliputi kecamatan Bandongan, Tempuran, Sawangan, Grabag, Srumbung, dan Dukuh dengan persebaran totalnya seluas 18.433 ha. Daerah yang memiliki persen kelerengan sebesar $>45 \%$ dengan tingkatan sangat curam meliputi Kecamatan Windusari, Kaliangkrik, Kajoran, Tempuran, Salaman, Borobudur, Dukuh, Sawangan, Ngablak, Pakis, dan Grabag dengan persebaran totalnya seluas 8.528 ha. Daerah dengan kemiringan lereng sangat curam pada umumnya merupakan daerah pegunungan dan perbukitan.

\section{Curah Hujan Tahunan}

Curah hujan tahunan Kabupaten Magelang diperoleh dari pengolahan data CHIRPS yang 
kemudian dikelaskan menggunakan klasifikasi distribusi frekuensi. Wilayah Kecamatan Windusari, Bandongan, Secang, Grabag, Ngablak, Tegalrejo, Candimulyo, Mertoyudan, Tempuran, dan Ngluwar memiliki rata-rata curah hujan tahunan sebesar 2.041-2.313 mm/tahun. Sementara itu, rata-rata curah hujan tahunan sebesar 2.313-2.585 $\mathrm{mm} /$ tahun tersebar pada kecamatan Windusari, Kaliangkrik, Kajoran, Salaman, Borobudur. Mungkid, Muntilan, Salam, Srumbung, Dukuh, Sawangan, Pakis dan sebagian kecil Kecamatan Grabag. Rata-rata curah hujan tahunan sebesar 2.585-2.856 $\mathrm{mm} /$ tahun tersebar pada kecamatan Dukuh, Kajoran, dan Windusari. Wilayah Kecamatan Kaliangkrik dan Windusari memiliki rata-rata curah hujan tahunan sebesar 2.856-3.128 $\mathrm{mm} /$ tahun. Rata rata curah hujan tahunan tertinggi dengan rentang 3.128-3.400 mm/tahun terdapat pada sebagian kecil Kecamatan Ngablak, Pakis, Sawangan, Windusari, Kaliangkrik, dan Kajoran (Gambar 5).

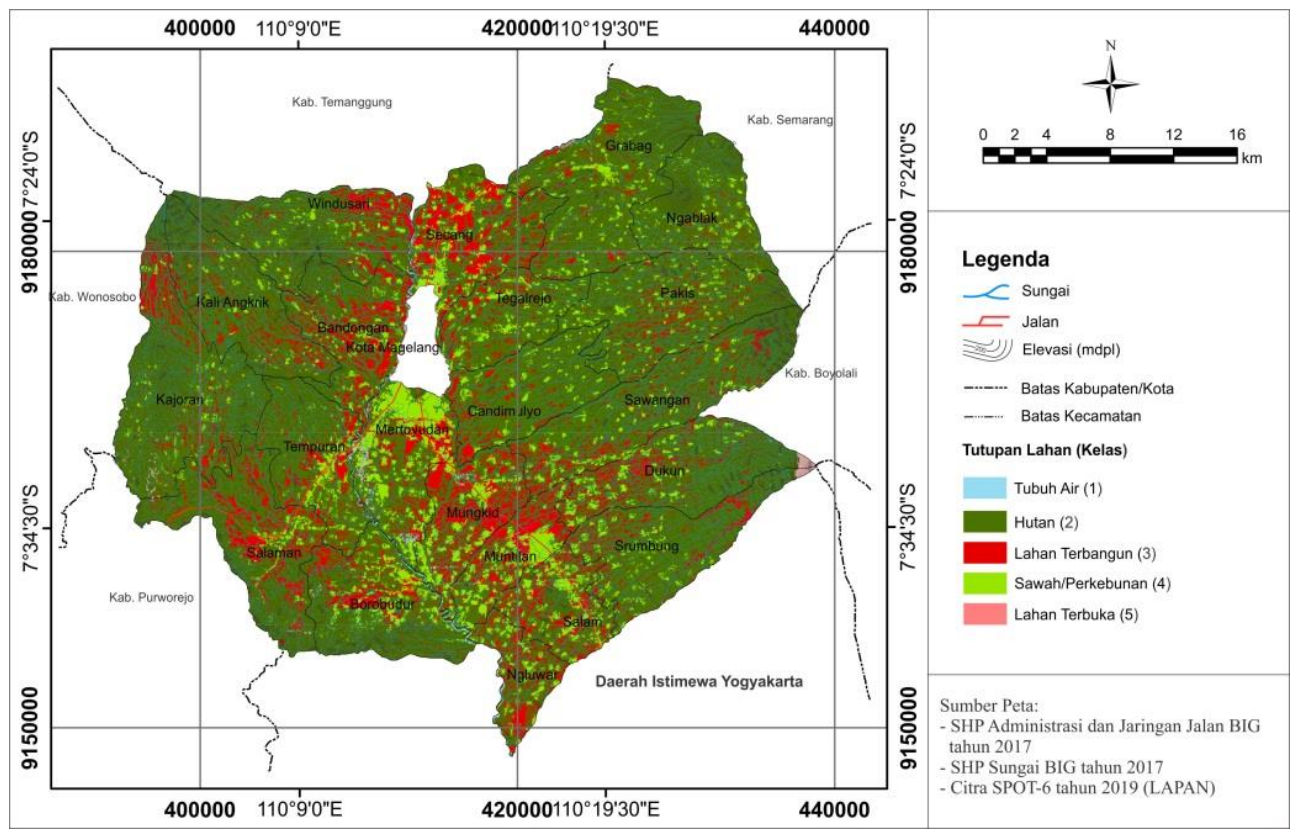

Gambar 3. Peta Tutupan Lahan Kabupaten Magelang

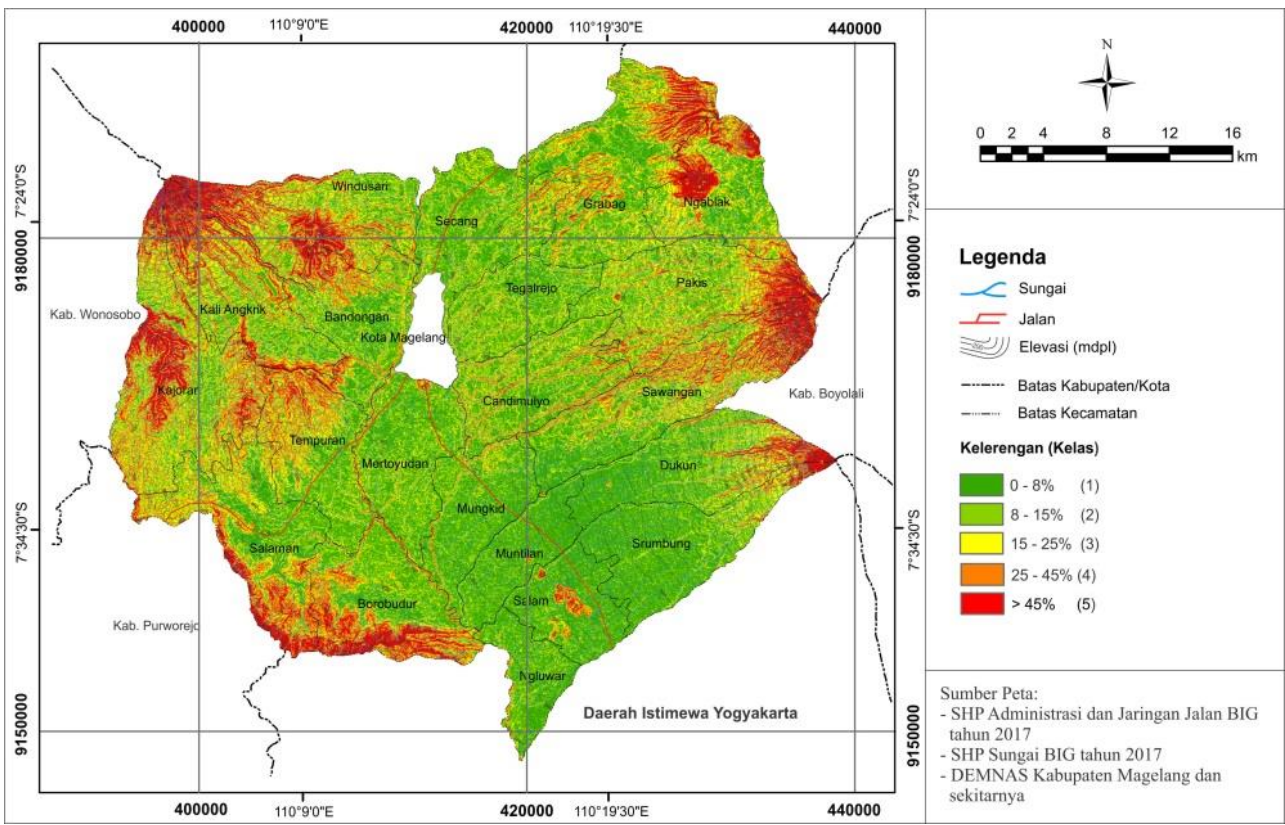

Gambar 4. Peta Kemiringan Lereng Kabupaten Magelang 


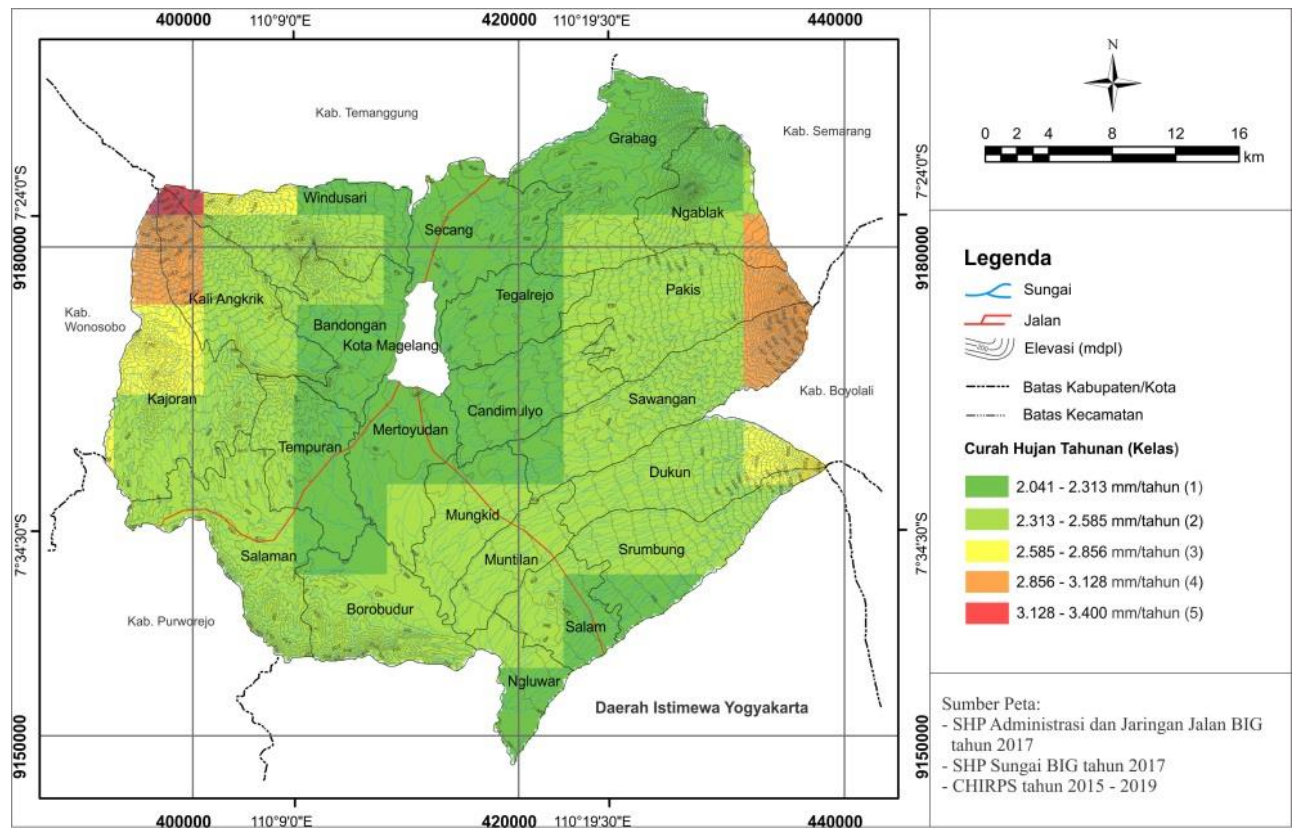

Gambar 5. Peta Curah Hujan Tahunan Kabupaten Magelang

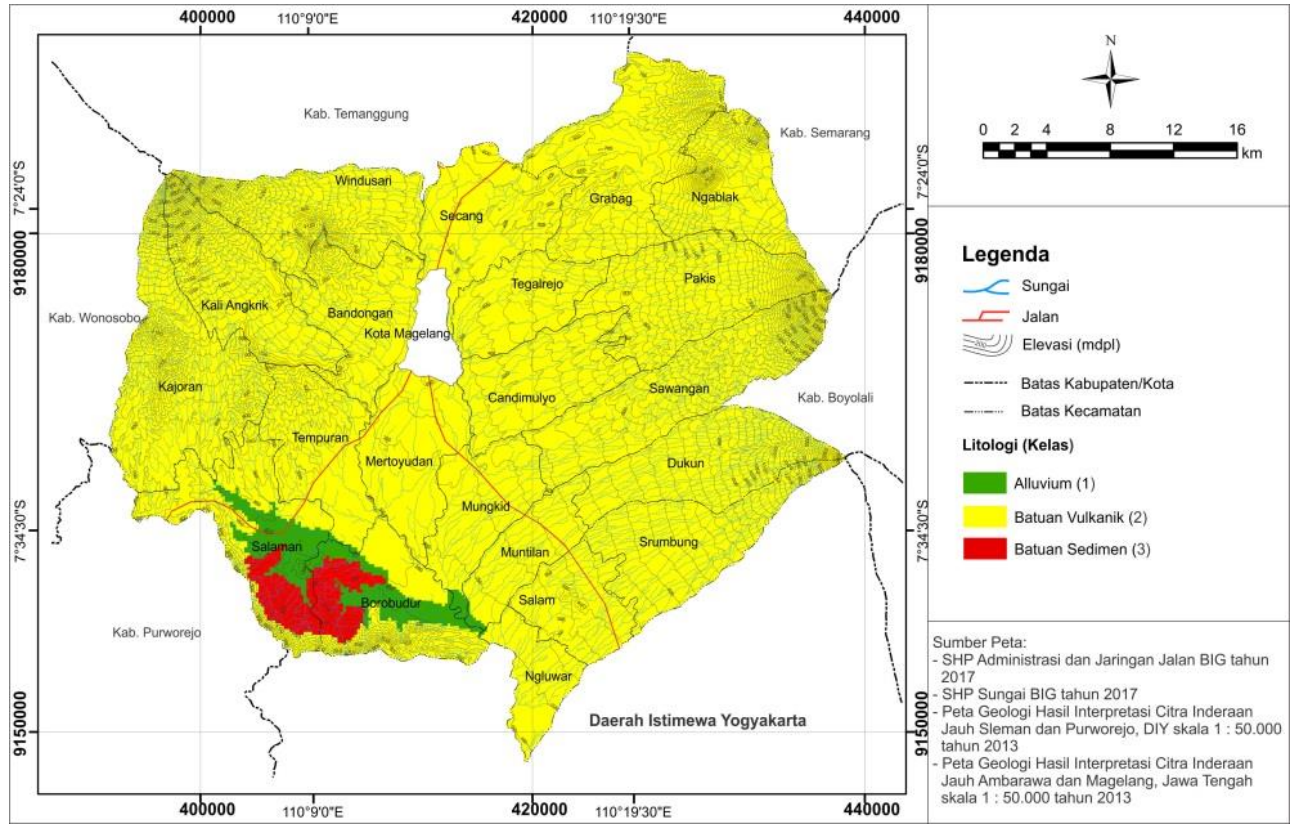

Gambar 6. Peta Persebaran Litologi Kabupaten Magelang

\section{Persebaran Litologi}

Persebaran litologi di Kabupaten Magelang didapatkan dari peta geologi interpretasi inderaan jauh serta hasil peninjauan ulang di lapangan. Dari hasil peninjauan ulang di lapangan, persebaran formasi batuan secara umum memiliki kesamaan dengan peta geologi hasil interpretasi citra inderaan jauh. Dalam peninjauan ulang di lapangan terdapat 45 stasiun pengamatan. Dari hasil peninjauan tersebut kemudian persebaran litologi diklasifikasikan menjadi tiga kelas berdasarkan klasifikasi
Puslitanak tahun 2004, yaitu batuan vulkanik, batuan sedimen, dan alluvium. Pada daerah penelitian didominasi oleh batuan vulkanik yang tersebar pada hampir keseluruhan wilayah Kabupaten Magelang (Gambar 6).

\section{Pembobotan Metode AHP}

Hasil pengolahan data dari kuesioner perbandingan AHP oleh responden, mendapatkan kombinasi pembobotan parameter peta rawan longsor yang menjadi acuan dalam proses pembobotan akhir peta rawan longsor Kabupaten 


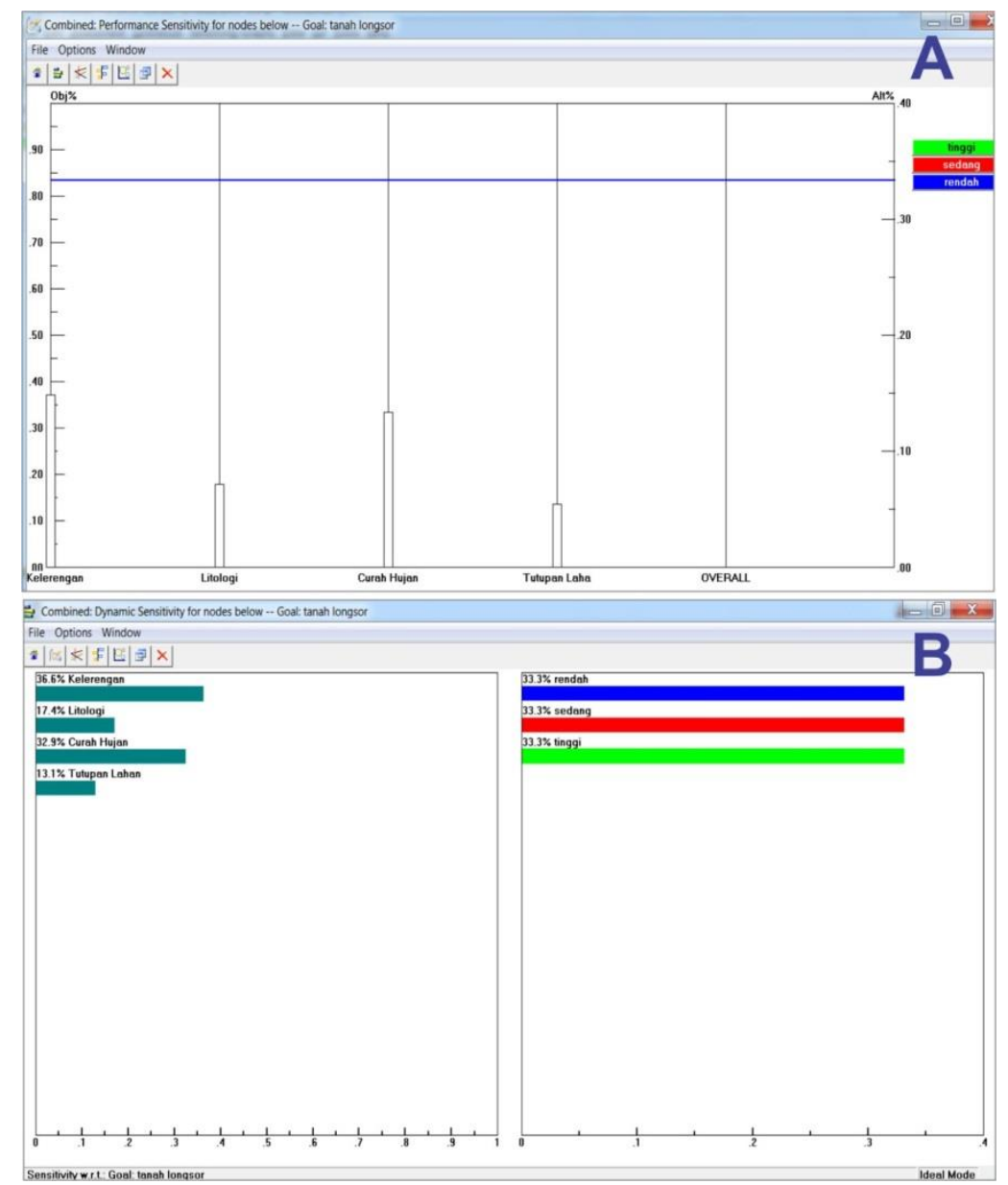

Gambar 7. A: Tampilan grafik Performance sensitivity, B: Tampilan grafik Dynamic sensitivity

Tabel 6. Bobot Parameter Penyebab Tanah Longsor Menggunakan Metode AHP

\begin{tabular}{lll}
\hline No & Parameter & Nilai Bobot \\
\hline 1 & Kemiringan lereng & $36,6 \%$ \\
2 & Litologi & $17,4 \%$ \\
3 & Curah hujan & $32,9 \%$ \\
4 & Tutupan Lahan & $13,1 \%$ \\
\hline
\end{tabular}

Magelang. Hasil kombinasi dari keseluruhan responden yang memiliki nilai $\mathrm{CR}<0,1$ ditampilkan pada Gambar 7. nilai bobot setiap parameter penyebab tanah longsor menggunakan penilaian AHP disajikan pada Tabel 6.

\section{Potensi Tanah Longsor Kabupaten Magelang}

Potensi tanah longsor Kabupaten Magelang didapatkan dari hasil overlay peta parameter dengan pembobotan menggunakan metode AHP menghasilkan peta yang ditunjukan pada Gambar 8 .
Berikut merupakan penjelasan tiap kelas rawan longsor dengan persebarannya di wilayah Kabupaten Magelang.

1. Daerah Rawan Longsor Rendah

Daerah dengan kelas rawan longsor rendah berada pada umumnya daerah ini berada pada wilayah dengan topografi datar hingga landai, kemiringan lereng berkisar antara 0\%-15\%. Di samping itu, kecamatan dengan tingkat rawan longsor rendah ini juga tersusun oleh batuan vulkanik serta alluvium, dan memiliki curah hujan tahunan sebesar 2.041-2.585 $\mathrm{mm} /$ tahun. Tutupan lahan pada daerah ini secara keseluruhan berupa tubuh air, hutan, lahan terbangun, dan sawah/perkebunan. Pada peta sebaran rawan longsor daerah dengan tingkatan rendah ditandai dengan warna hijau.

2. Daerah Rawan Longsor Sedang

Daerah dengan kelas rawan longsor sedang berada pada pada wilayah topografi landai hingga curam, dengan kemiringan lereng 
berkisar antara 8\%-40\%. Di samping itu, pada kecamatan dengan kelas rawan longsor sedang ini umumnya tersusun oleh batuan vulkanik, dan memiliki curah hujan tahunan sebesar 2.041-2.585 mm/tahun. Tutupan lahan pada daerah ini secara keseluruhan berupa lahan terbangun, sawah/ perkebunan, dan hutan, Pada peta sebaran rawan longsor daerah dengan tingkatan sedang ditandai dengan warna kuning.

\section{Daerah Rawan Longsor Tinggi}

Secara umum wilayah dengan tingkat rawan longsor tinggi berada pada topografi curam hingga sangat curam, kemiringan lerengnya berkisar antara $25 \%$ hinga lebih besar dari $45 \%$. Di samping itu pada wilayah ini secara keseluruhan tersusun oleh jenis batuan berupa batuan sedimen dan batuan vulkanik. Curah hujan pada daerah ini cukup bervariasi yaitu 2.585-3.400 mm/tahun. Tutupan lahan pada daerah ini didominasi oleh sawah/perkebunan, namun juga terdapat lahan terbangun, hutan, dan lahan terbuka.

\section{Validasi Peta Rawan Longsor dengan \\ Data Lapangan}

Validasi peta rawan longsor dilakukan dengan membandingkan kecocokan data hasil analisis dengan data lapangan. Data lapangan yang dimaksud adalah riwayat kejadian longsor pada daerah penelitian yang didapatkan dari BPBD Kabupaten Magelang tahun 2017-2019. Beberapa dokumentasi lapangan berdasarkan titik kejadian longsor tersebut dapat dilihat pada Gambar 9. Hasil verifikasi kedua data tersebut dihitung dengan menggunakan perhitungan matriks konfusi pada Tabel 7. Selanjutnya dihitung nilai akurasi keseluruhan data analisis peta rawan longsor. Nilai akurasi keseluruhan $=$ $((7+4+6) / 21) \times 100 \%=80,95 \%$.

\section{PEMBAHASAN}

Hasil pengolahan parameter penyebab tanah longsor Kabupaten Magelang secara umum menunjukkan pola yang hampir sama. Pada bagian terluar Kabupaten Magelang terdiri dari kelerengan yang tinggi yaitu nilai kelas 4-5, begitu pula dengan parameter curah hujan yang terdiri dari nilai kelas 4-5. Hal ini disebabkan karena adanya keterkaitan antara topografi dengan intensitas curah hujan pada suatu wilayah. Rafi'i (2005) menyebutkan bahwa curah hujan memiliki hubungan linier dengan

Tabel 7. Matriks Konfusi Perbandingan Data Lapangan dan Hasil Analisis Peta

\begin{tabular}{llcccc}
\hline \multicolumn{5}{c}{ Data Lapangan } \\
\hline Analisis & Kelas & Tinggi & Sedang & Rendah & Total \\
Peta & Tinggi & 7 & 3 & 0 & 10 \\
& Sedang & 0 & 4 & 0 & 5 \\
& Rendah & 0 & 0 & 6 & 6 \\
& Total & 7 & 7 & 7 & 21 \\
\hline
\end{tabular}

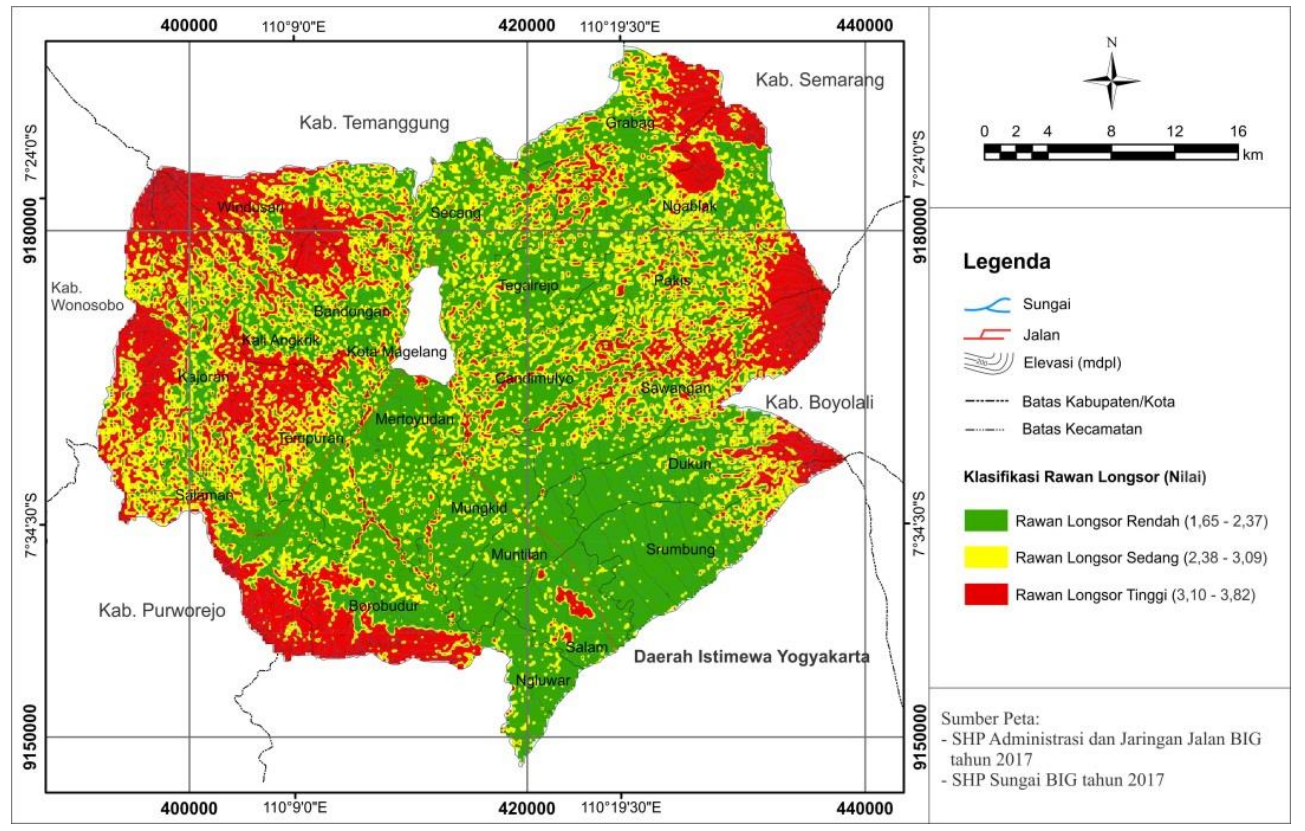

Gambar 8. Peta Sebaran Daerah Rawan Longsor Kabupaten Magelang 

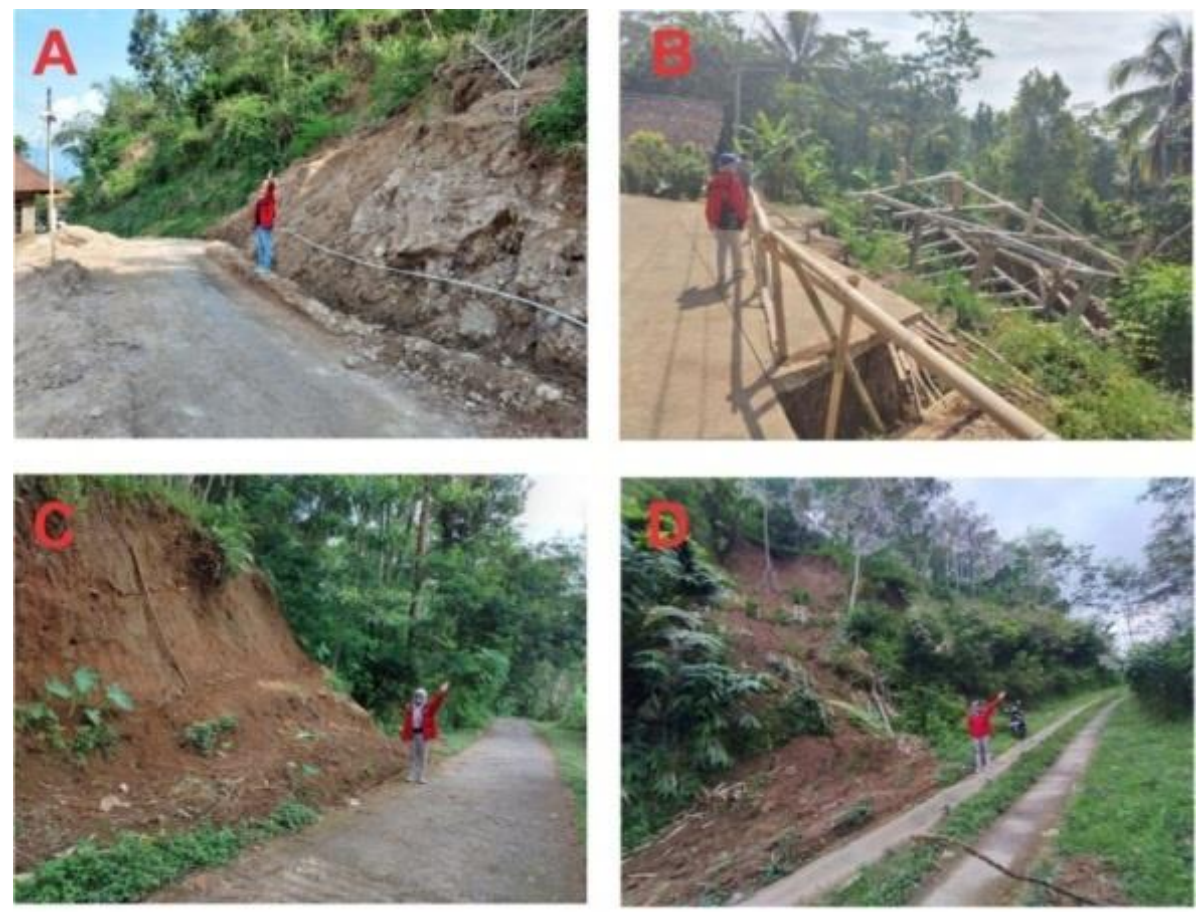

Gambar 9. Dokumentasi Kejadian Longsor di Lapangan (A) Kecamatan Windusari, (B) Kecamatan Kaliangkrik, (C) Kecamatan Salaman, (D) Kecamatan Borobudur.
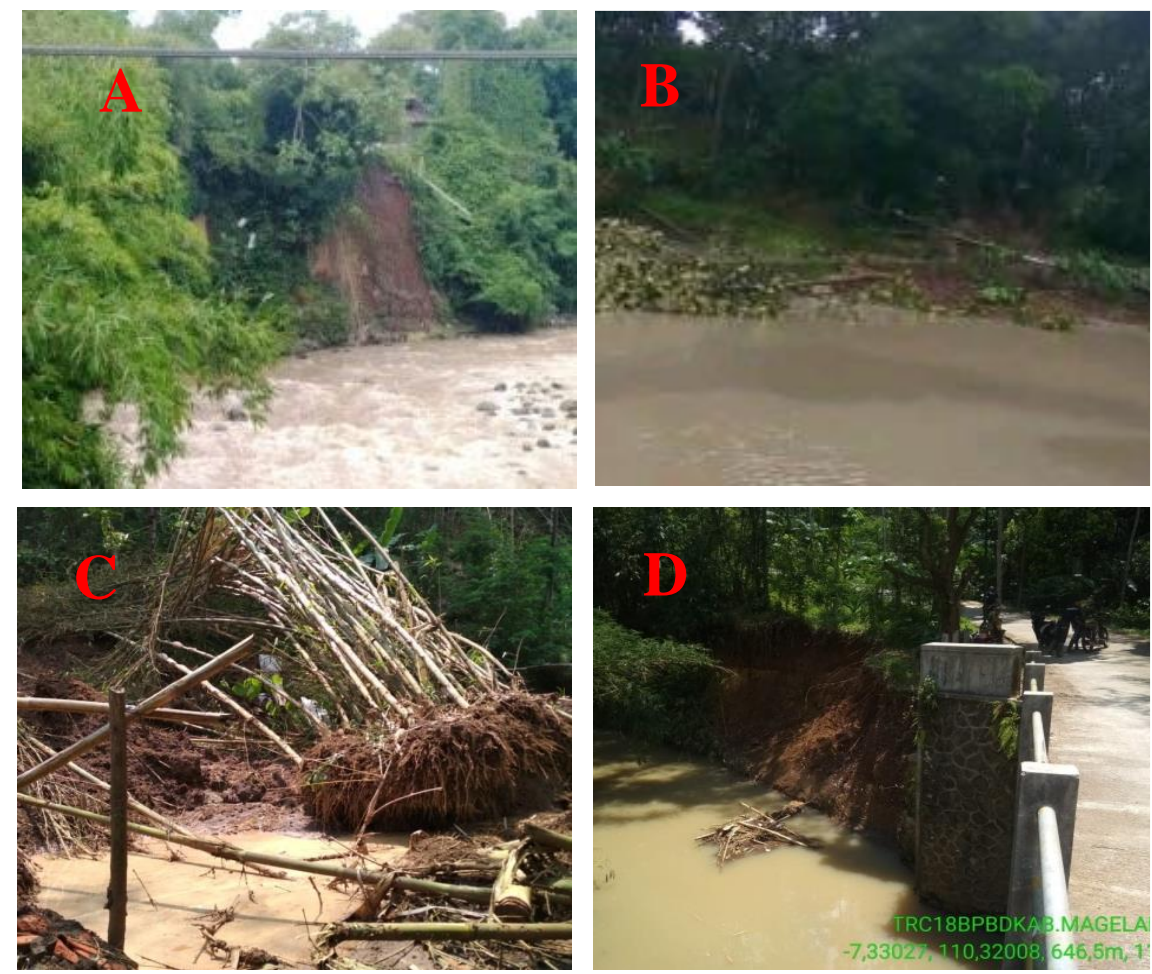

Gambar 10. Titik Kejadian Longsor (A dan B) Kecamatan Dukun, (C dan D) Kecamatan Srumbung (Sumber: BPBD Kabupaten Magelang)

ketinggian tempat atau topografi yang biasanya dihitung dengan persamaan regresi linier. Selain itu, pada umumnya pada bagian terluar Kabupaten Magelang memiliki kelerengan yang tinggi karena terdiri dari Pegunungan, berupa Gunung Merapi, Gunung Merbabu, dan Gunung Sumbing. Hal ini menyebabkan pada wilayah tersebut umumnya tersusun oleh batuan vulkanik 
yang merupakan produk dari gunung api yang mengelilingi Kabupaten Magelang tersebut.

Berdasarkan hasil validasi dengan membandingkan antara peta rawan tanah longsor hasil analisis dengan riwayat kejadian longsor di Kabupaten Magelang tahun 2017-2019 terdapat sedikit error, yaitu terdapat beberapa titik kejadian longsor pada wilayah dengan tingkat rawan longsor yang rendah. Ketidaksesuaian ini dapat ditemukan pada sebagian Kecamatan Srumbung dan Dukun yang termasuk dalam wilayah dengan tingkat rawan longsor rendah dan ditandai dengan warna hijau. Pada umumnya tanah longsor pada titik tersebut terjadi ketika banjir dan tebing sungai mengalami erosi (Gambar 10) sedangkan tutupan lahan berupa tubuh air memiliki nilai kelas 1 atau dianggap paling aman dalam terjadinya tanah longsor dibandingkan dengan tutupan lahan yang lainnya (Puslitanak, 2004). Selain itu pada wilayah kejadian ini secara umum termasuk dalam kelerengan dengan kelas 1-2, curah hujan kelas 12 , dan litologi berupa batuan vulkanik (nilai kelas 2).

Selanjutnya secara keseluruhan, dari hasil perhitungan validasi dengan menggunakan metode matriks konfusi menunjukan hasil tingkat akurasi $80,95 \%$. Nilai ini menunjukan bahwa hasil analisis peta sebaran rawan longsor sudah cukup sesuai dengan data lapangan. Hal ini berarti pemilihan metode penginderaan jauh dan pembobotan menggunakan AHP memiliki tingkat akurasi yang baik. Hal ini juga dibuktikan oleh Yalcin (2008) yang melaksanakan penelitian mengenai pemetaan daerah rawan longsor menggunakan penginderaan jauh, AHP dan bivariat statistik. Namun, penggunaan metode AHP dianggap lebih akurat dibandingkan metode bivariat statistik. Selain itu Zhang dkk (2016) juga melakukan perbandingan antara metode AHP dengan faktor pembobotan untuk menganalisis daerah rawan longsor. Hasilnya menunjukkan bahwa penggunaan metode AHP memiliki tingkat ketelitian yang lebih tinggi dibandingkan faktor pembobotan.

\section{KESIMPULAN}

Persebaran daerah rawan longsor Kabupaten Magelang dapat dibagi menjadi tiga zona, yaitu rawan longsor rendah, rawan longsor sedang, dan rawan longsor tinggi. Zona rawan longsor rendah mencakup Kecamatan Ngluwar, Muntilan,
Mungkid, Mertoyudan, Salam, dan Srumbung. Zona rawan longsor sedang mencakup Kecamatan Bandongan, Candimulyo, Dukuh, Secang, dan Tegalrejo. Zona rawan longsor tinggi mencakup Kecamatan Borobudur, Grabag, Kajoran, Kaliangkrik, Ngablak, Pakis, Salaman, Sawangan, Tempuran

\section{UCAPAN TERIMAKASIH}

Terimakasih kepada PUSFATJA LAPAN, BPBD Kabupaten Magelang, dan Pusat Survey Geologi yang menyediakan keperluan data terkait penelitian ini.

\section{DAFTAR PUSTAKA}

ASPRS. 2007. Digital Elevation Model Technologies and Aplication : The DEM Users Manual. 2nd Edition (red)David F.maune. Bethesdha: Maryland.

Badan Informasi Geospasial. 2011. DEMNAS Kabupaten Magelang dan sekitarnya, dari (http://tides.big.go.id/DEMNAS/)

Badan Informasi Geospasial. 2008. DEMNAS Seamless Digital Elevation Model(DEM) dan Batimetri Nasional, dari http://tides.big.go.id/DEMNAS/ (diakses pada 13 Maret 2020)

BDPJN LAPAN. 2018. Deskripsi Dataset - SPOT 6. Jakarta catalog.lapan.go.id/catalog/help/bdpjndeskripsi.html)

Bera, S., Guru, B., dan Ramesh, V. 2018. Evaluation pf landslides susceptibility models: a comparative study on the part of Western Ghat Region,India. Remote Sensing Applications: Society and Environment

BNPB, 2012. Peraturan Kepala Badan Nasional Penanggulangan Bencana nomor 02 tahun 2012 tentang Pedoman Umum Pengkajian Risiko Bencana

BPBD Kabupaten Magelang, 2020. Histori Kejadian Longsor Kabupaten Magelang tahun 2017-2019. (http://sikk.bpbdmagelang.id/)

CHC (Climate Hazard Center), 2020. CHIRPS (Climate Hazards Group InfraRed Precipitation with Station) 2.0 tahun 2015-2019. UC Santa Barbara.

Direktorat Jendral Reboisasi dan Rehabilitasi Lahan, 1986. Pedoman Penyusunan Pola Rehabilitasi Lahan dan Konservasi Tanah. Jakarta: Departemen Kehutanan.

Febrianti, N., Pasaribu, J. Mo., dan Sulma, S., 2015. Analisis Ruang Terbuka Hijau di DKI Jakarta Menggunakan Data SPOT 6. Prosiding Pertemuan Ilmiah Tahunan Masyarakat Ahli Penginderaan Jauh Indonesia XXII. 
Funk, C., Peterson, P., Landsfeld, M., Pedreros, D., Verdin, J., Shukla, S., Husak, G., Rowland, J., Harrison, L., Hoell, A., dan Michaelsen, J., 2015. The Climate Hazards Infrared Precipitation with Station - a New Environmental Record For Monitoring Extremes. Earth System Science Data, 2:150066.

Gorum, T., Fan, X., van Westen, C.J., Huang, R.Q., $\mathrm{Xu}$, Q., Chuan, T., dan Wang, G., 2011. Distribution Pattern of Earthquake-Induced Landslides triggered by the 12 May 2008 Wenchuan Earthquake. Geomorphology 133, 152167.

Gorum, T., Korup, O., van Westen, C.J., van der Meijede, M., Xu, C., dan van der Meer, F.D., 2014. Why so few? Landslides triggered by the 2002 Denali earthquake, Alaska. Quaternary Science Review 95, hal.80-94.

Kayastha, P., Dhital, M.R., dan Smedt, F.D., 2019. Application of the analytical hierarchy process (AHP) for landslide susceptibility mapping: A case study from the Tinau watershed, west Nepal. Computers \& Geosciences 52, hal.398-408.

LAPAN (Lembaga Penerbangan dan Antariksa Nasional). 2018. Citra SPOT 6 Pan Sharpening daerah Kabupaten Magelang dan Sekitarnya.

Lodhi, M.A. 2011. Earhtquake-induced landslides mapping in the western Himalays using medium resolution ASTER imagery. International Journal of Remote Sensing 32(19), hal.5331-5346.

Owen, L.A., Kamp, U., Khattak, G.A., Harp, E.L., Keefer, D.K., dan Bauer, M.A. 2008. Landslides triggered by the October 8, 2005, Kashmir earthquake. Geomorphology 94, hal.1-9.

Permen PU No.22/PRT/M/2007 tentang Pedoman Penataan Ruang Kawasan Bencana Tanah Longsor. Jakarta: Departemen Pekerjaan Umum Direktorat Jenderal Penataan Ruang.

Pradhan, B. 2010. Remote sensing and GIS-based landslide hazard analysis and cross-validation using multivariate logistic regression model on three test areas in Malaysia. Advances in Space Research 45, hal. 1244-1256

Pusat Penelitian dan Pengembangan Tanah dan Agroklimat. 2004. Laporan Akhir Pengkajian Potensi Bencana Kekeringan, Banjir dan Longsor di Kawasan Satuan Wilayah Sungai CitarumCiliwung, Jawa Barat Bagian Barat Berbasis Sistem Informasi Geografi. Bogor: Pusat Penelitian dan Pengembangan Tanah dan Agroklimat.

Rafi'i. 1995. Meteorologi dan Klimatologi. Bandung: Penerbit Angkasa.

Saaty, T.L. 1994. The Fundamental of Decision Making and Priority Theory With the Analytic Hierarchy Process. Pitssburgh: RWS Publications.

Surono. 2013. Peta Geologi Hasil Interpretasi Citra Inderaan Jauh Ambarawa, Purworejo dan
Magelang Jawa Tengah skala 1 : 50.000 . Bandung: Pusat Survei Geologi

Temesgen, B., Mohammed, M.U., dan Korme. T. 2001. Natural Hazard Assessment Using GIS and Remote Sensing Methods, with Particular Reference to the Landslides in the Wondogenet Area, Ethiopia. Physics and Chemistry of the Earth (C), 26(9), hal. 665-615

Yalcin, A. 2008. GIS-based landslide susceptibility mapping using analytical hierarchy processand bivariate statistics in Ardesen (Turkey): Comparisons of results and confirmation. Catena 72, hal.1-12.

Zhang, G., Cai, Y., Zheng, Z., Liu, Y., dan Huang, K. 2016. Integration of the Statistical Index Method and the Analytic Hierarchy Process technique for the assessment of landslide susceptibility in Huizhou, China. Catena 142, hal.233-244. 